\title{
Case-baseret undervisning - et overset værktøj for klassiske humanistiske fag
}

Caroline Schaffalitzky de Muckadell, adjunkt, Institut for Kulturvidenskaber, Syddansk Universitet.

Annika Hvithamar, lektor, Institut for Historie, Syddansk Universitet.

\section{Reviewet artikel}

Case-baseret undervisning er blevet udbredt, fordi den er velegnet til at træne analyse af problemer med henblik på at foreslå løsninger. Denne artikel argumenterer for, at klassiske humanistiske fag også bør tage metoden til sig, selvom fagene typisk ikke har problemløsning som afgørende målsætning. Udviklingen skal dog hjælpes på vej.

Lektor Petersen fra det humanistiske fakultet skal til at planlægge næste uges undervisning. Hun ved fra forskningen, at uanset hvor meget hun gør sig umage med sine forelæsninger, betyder den faldende læringskurve, at kun en forsvindende del af stoffet vil blive hængende hos de studerende i længere tid. Hun kan indlægge forskellige aktiverende elementer, der kan afhjælpe dette, eller hun kan gå mere drastisk til værks: Hun kan forberede næste uges tema som case-baseret undervisning. Det er dog næppe sandsynligt, at hun vil vælge at gøre dette. For på trods af at forskning viser, at denne type undervisning har adskillige styrker, har klassiske, humanistiske fag ikke taget case-baseret undervisning til sig. Hvilke grunde kan der være til dette? Og hvad skal der til, hvis billedet skal ændres?

\section{Hvad er case-baseret undervisning?}

Case-baseret undervisning er karakteriseret ved, at undervisningen opbygges omkring en case. En case er groft sagt et virkeligt (eller i hvert fald realistisk) scenarie, som indeholder komplekse problemstillinger, der egner sig til fx teoretisk udredning eller praktisk problemløsning. I case-beskrivelsen indgår arbejdsspørgsmål og typisk også baggrundsmateriale eller henvisninger hertil. Case og spørgsmål er formuleret sådan, at det ikke giver sig selv, hvordan den bør håndteres, og herved adskiller case-undervisningen sig fra fx regneeksempler i naturvidenskabelige fag, idet den udfordrer studerende til at analysere, anvende teoretiske modeller og/eller træffe beslutninger. Således adskiller 'case' sig i denne artikels betydning fra brugen af 'case' som betegnelse for blot et praktisk eksempel. 
Selve undervisningen organiseres således, at de studerende først får adgang til casen og de tilhørende spørgsmål. Efter de studerende har arbejdet med stoffet (alene eller i grupper), er det underviserens opgave at facilitere en diskussion, der kan bringe de studerende gennem spørgsmålene. Det teoretiske baggrundsmateriale kan enten præsenteres før casen (hvis man sigter mod en detaljeret forståelse allerede i udgangspunktet), sammen med casen (hvis de studerende selv skal orientere sig i materialet) eller efter casen (hvis casen skal motivere og åbne det teoretiske stof).

Der er mange typer af case-baseret undervisning og mange beslægtede undervisningsformer. Der er da heller ikke generel enighed om, hvordan man mere abstrakt skal definere og afgrænse den. I måden den er organiseret på, adskiller caseundervisningen sig imidlertid fra andre undervisningsformer, som er centreret om undersøgelse af problemer såsom 'Just-in-Time-Teaching' og 'Problem Based Learning' (PBL) (se fx Nilson, 2010, s. 175-179 for disse og andre eksempler), og den ser det fx ikke som et mål, at studerende selv skal identificere de centrale problemer. I praksis betyder det bl.a., at det skriftlige materiale, som udleveres i forbindelse med en case, er mere komplet, detaljeret og strammere struktureret end det tilsvarende for PBL. Underviserens rolle er også tænkt forskelligt: I case-baseret undervisning forventes det, at underviseren leder og modererer diskussionen, mens det i PBL forventes, at såvel initiativ som moderation i højere grad er lagt op til de studerende (se fx Savery, 2006, s. 15-16). Der er imidlertid også klare fællestræk mellem case-baseret undervisning og PBL og vi vil derfor ikke i det følgende skelne alt for skarpt mellem de to metoder. ${ }^{1}$

Forskning har vist, at den case-baserede undervisning dels kan fremme studerendes engagement, læring og kompetencer i forhold til at analysere, reflektere og tage beslutninger, dels har den vist sig egnet til at forberede studerende til den komplekse virkelighed (se fx Jonassen \& Hernandez-Serrano, 2002; Lundeberg et al., 1999). Dette har givet den case-baserede tilgang en vis udbredelse i professionsfag som $\mathrm{fx}$ sundhedsfagene, jura og samfundsvidenskab, fordi den er velegnet til at forberede studerende på de opgaver, de skal løse efter endt uddannelse (se fx Nilson, 2010, s. 181-185 for en oversigt over forskning i fordele ved case-baseret undervisning). Det betyder dog på ingen måde, at case-baseret undervisning har afløst den traditionelle undervisning på disse fakulteter, men i modsætning til de klassiske humanistiske fag har undervisere inden for professionsfagene større kendskab til metoden og flere værktøjer og etableret forskning i case-baseret undervisning til deres rådighed.

\footnotetext{
${ }^{1}$ Tilsvarende skal det bemærkes, at vi heller ikke vil beskæftige os med diskussionen om de forskellige typer af cases. Inden for genren skelner man fx mellem beslutningscases, sammenligningscases, demonstrationscases, kvantitative cases, case-serier og mini-cases, men til det foreliggende formål er det tilstrækkeligt at notere, at case-undervisning kan tilpasses forskellige typer af læringsmål og praktiske rammer.
} 


\section{Et forsvar for cases på humaniora}

Udbredelsen af case-baseret undervisning har imidlertid efterladt humaniora forholdsvis upåvirket. I praksis har de fornyelser, der er sket på de humanistiske fag, i det væsentligste ikke brudt med idealet om den velkendte forelæsning, selvom man længe (jf. fx Bligh, 1972) har kendt til denne metodes svagheder. På trods af opbrud i traditionerne (fx illustreret ved RUCs projektbaserede tilgang også i klassiske, humanistiske fag), tyder studieordninger og anekdotisk erfaring på, at klassiske, humanistiske fag stadig hovedsageligt har forelæsningsbaseret undervisning (egentlige overordnede kortlægninger af dette synes desværre ikke at være tilgængelige). At case-undervisningen ikke har vundet indpas i de klassiske, humanistiske fag afspejler sig både i forskningen i case-undervisning (som i alt væsentligt er fokuseret på effekterne inden for $\mathrm{fx}$ sundhedsvidenskab og handelsuddannelser), i litteraturen om case-undervisning og i materialesamlinger i form af databaser. Det sidste illustreres konkret ved fraværet af databaser for humanistiske cases. Selvom der findes cases med relevans for humanistiske fag, er deres antal forsvindende i forhold til den samlede mængde af tilgængelige undervisningscases.

I denne artikel beskriver og udfordrer vi mulige historiske, strukturelle og praktiske grunde til, at det forholder sig sådan, og vi inddrager konkrete eksempler i et forsvar for at bruge case-baseret undervisning inden for klassiske, humanistiske fag. ${ }^{2}$

Blandt de forskellige typer af cases har vi valgt at fokusere på såkaldte 'beslutningscases'. Disse er cases, der - i hvert fald på overfladen - stiller den opgave at komme med forslag til, hvordan man løser et konkret problem. Grunden til at vi vælger denne form, er, at den, i modsætning til fx analysecases, ligger langt væk fra klassisk, humanistisk undervisning og derved kan sætte argumentationen på spidsen. Desuden er det vores egen erfaring, at netop denne type case-undervisning virker stærkt engagerende på studerende.

\section{Hvorfor fravælges cases?}

En banal forklaring på, at der ikke vælges case-baseret undervisning i klassiske, humanistiske fag er, at der ikke er tradition for det. Men hvorfor er humaniora næsten uberørt af den udvikling, som har præget undervisningen på andre fakulteter? I det følgende præsenterer og diskuterer vi en række mulige grunde til, at case-baseret undervisning endnu ikke har slået rod i værktøjskassen for humanistiske undervisere. I denne forbindelse gør vi os visse forudsætninger, nemlig at den hidtidige og

\footnotetext{
2 "Klassiske humanistiske fag" er naturligvis en noget uklar kategori. Her betyder den noget i retning af fag som ikke er professionsrettede (sådan som fx cand.negot. eller logopædi) og hvor historisk viden og/eller abstrakte teoretiske modeller er af mere central betydning end praktisk opgaveløsning. Vores egne erfaringer er gjort $\mathrm{i}$, hvad vi opfatter som klassiske humanistiske fag, nemlig religionshistorie og videnskabsteori.
} 
omfattende forskning i case-baseret undervisning i det store hele har ret i sin påvisning af positive effekter for motivation, læringsudbytte mv.

Det betyder bl.a., at visse grunde til ikke at vælge cases afvises allerede i udgangspunktet. Der er således ingen grund til at tro at studerende skulle være afvisende overfor case-baseret undervisning. Tværtimod viser al forskning i case-undervisning, at såvel studerende som undervisere foretrækker cases, når de først er blevet præsenteret for denne form (se fx Strobel \& van Barneveld, 2009). Måske fordi den ud over læringsudbyttet også har positiv effekt på deres faglige engagement og selvtillid (se fx Hmelo-Silver, 2004 og Lundeberg \& Yadav, 2006). Tilsvarende vil vi ikke diskutere, om case-undervisning skulle sænke det faglige niveau eller skade de studerendes arbejdsmoral.

Ideen om humanioras egenart

Meget tyder på, at en central forklaring på, hvorfor cases ikke har vundet indpas i humaniora, skal findes i opfattelsen af forskelle mellem klassiske, humanistiske og andre fag. Den case-baserede undervisning har sin oprindelse ved Harvard Law School, hvor undervisning efter denne metode var udbredt allerede i 1915. I 1918 blev metoden indført ved Harvard Business School. For begge områders vedkommende blev implementeringen af metoden støttet såvel institutionelt som gennem eksterne bevillinger. Men da metoden blev søgt implementeret ved Harvard Graduate School of Education blev den afvist. Begrundelsen var, at metodens vægtlægning på at lære studenterne at tage beslutninger ikke egnede sig for discipliner, hvor det er problemet i sig selv, der er i fokus for læringen. Som resultat blev de humanistiske fag ikke inddraget i udviklingen af den case-baserede metode (se Merseth 1991 for et historisk perspektiv på den manglende implementering af case-baseret undervisning på humaniora).

Idéen om humanioras egenart betød et negativt fokus på beslutningstagningsaspektet som det væsentlige, og det blev derfor på forhånd opgivet at tilpasse metoden til humanistiske fag. Desuden betød den manglende institutionelle støtte, at der ikke var et incitament for underviserne til at investere den (store) mængde tid, som udarbejdelsen af case-baseret undervisning kræver. Der blev heller ikke udviklet samarbejde med institutioner ( $\mathrm{f} x$ virksomheder) uden for universiteterne, som kunne have interesse $i$ at levere cases til undervisningen. Som Merseth fremhæver, er humaniora dermed gået glip af både forskningsmateriale, økonomisk støtte og interessante samarbejdspartnere (Merseth, 1991, s. 245-246). Så på trods af, at case-baseret undervisning kan findes rundt omkring på humaniora, er den aldrig blevet implementeret strukturelt i fx studieordninger, som det er tilfældet med andre fakulteter (se fx Foran, 2005). Der eksisterer fortsat en udbredt antagelse om, at brugen af cases bør være forbeholdt uddannelser inden for professionsfag, der sigter mod en anvendelseskon- 
tekst kendetegnet ved problemløsninger (se fx fremstillingerne i Nilson, 2010, s. 182 og Biggs \& Tang, 2009,, s. 138). Vi mener derimod, at denne indskrænkning er unødvendig og kan afvises ved at henvise til gode eksempler på humanistiske beslutningscases. For selvom mange humanistiske fag ikke naturligt har et problemløsningsaspekt, kan dette element kunstigt indføjes. Herved opnås case-metodens positive motivations- og læringseffekter, fordi de teoretiske perspektiver aktiveres gennem beslutningsaspektet. Opgaven for case-forfatteren bliver så blot at 'tænke baglæns' og skrive en historie, som måske har et beslutningsaspekt, men hvor selve beslutningen egentlig er underordnet. Et par (sjældne!) eksempler hentet fra casedatabasen Enduring Legacies, hvis cases tager udgangspunkt i indianske amerikaneres historie, kan illustrere ideen:

Casen "Whose History Should We Teach?" (Constantino \& Hurtado, 2007) beskriver en samtale i et lærerværelse i staten Washington, hvor man diskuterer, hvordan man kan leve op til nye retningslinjer, der opfordrer til at inkludere indianske stammers perspektiv i historieundervisningen. Lærerne er enige om, at dette skal gøres, men bliver hurtigt uenige om kendsgerningerne i forbindelse med en række historiske begivenheder. Ved at bede den studerende beslutte, hvordan undervisningsplanen skal skrues sammen, inddrages automatisk selve de historiske forløb, som lærerne i den delvist fiktive (omend realistiske) case strides om. Samtidig bevares det stærkt motiverende og aktiverende aspekt, fordi der er tale om en beslutningscase, som stiller krav til den studerende om at tage stilling til problemet.

En anden case beskriver det komplekse forløb, hvor der under et byggearbejde findes rester (herunder af mennesker) fra en historisk indiansk landsby (Wheeler \& Smith, 2009). Blandt de problemorienterede spørgsmål til de studerende er herefter dette: Hvordan kan man lave regler, der kan tage højde for lignende problemer i fremtiden? Det kan ikke lade sig gøre at besvare dette spørgsmål, uden også at behandle de læringsmål, som ligger gemt bag casen, herunder at have forstået den indianske kultur og historie, at kende til lovgivningen på området og at kunne analysere de kulturelle konflikter samt mediernes håndtering af sagen. Casen illustrerer således fint vores påstand om, at en problemcase implicit inddrager elementerne fra en analyse- og beskrivelsescase, samtidig med, at den motiverer, hvorfor de historiske og teoretiske aspekter er vigtige, og hvordan de får betydning i forhold til det praktiske eksempel.

Praktiske og strukturelle udfordringer for case-undervisning i humanistiske fag Selvom det altså er muligt at benytte case-metoden også i klassiske, humanistiske fag, betyder det ikke, at der ikke er mange udfordringer. Disse har at gøre med både teoretisk viden, praktiske erfaringer og strukturelle forhold. Den største forhindring for udbredelsen af case-baseret undervisning er formentlig mangel på kendskab til 
metoden. Hvis case-baseret undervisning skal blive en naturlig del af undervisningspaletten på klassiske, humanistiske fag, kræver det, at kendskabet til mulighederne udbredes, men det kræver også, at der er eksempler til rådighed som kan bruges som afsæt. Fag med tradition for case-baseret undervisning kan trække på store databaser, som opsamler cases, som andre så enten kan bruge eller finde inspiration i (der findes mange, men se eksempler på kendte databaser under henvisninger), mens noget tilsvarende ikke findes for humanistiske fag.

Kombineret med målrettet forskning i muligheder og metoder på området (måske med inspiration fra de fag, der har lange traditioner på området), kunne en sådan database være et nyttigt redskab i den indsats, der kræves til case-baseret undervisning. Der er nemlig også ressourcemæssige forhindringer for den case-baserede metode: En fuldt udarbejdet case fylder typisk et sted mellem 10 og 30 sider og har en undervisningsvejledning (en såkaldt teaching note) af tilsvarende størrelse. Hvis en større del af et givent kursus skal udgøres af cases, bliver undervisningsforberedelsen således langt mere tidskrævende, end når en klassisk forelæsning skal forberedes. Ud over faglig fortrolighed med stoffet, kræver den case-baserede undervisning også en portion kreativitet i arbejdet med at omsætte fx historisk eller abstrakt teoretisk stof til en vellykket case. Oftest begynder man som nævnt 'bagfra' med at formulere sine undervisningsmål, og derefter finder man så et virkeligt, eller i hvert fald realistisk, eksempel, som casen kan bygges op om. Og endelig skal man formulere de arbejdsspørgsmål, der skal guide diskussionen og sikre, at læringsmålene nås. Hvis der allerede eksisterede tilgængelige cases med tilhørende underviservejledninger, ville arbejdet med at skrive cases og vejledninger kunne lettes betydeligt.

Som det er nu, er det imidlertid en stor opgave at omforme den traditionelle undervisning, og det er derfor nødvendigt at overveje, hvordan man kunne gøre det mere attraktivt at prioritere denne opgave, frem for blot at fortsætte i det traditionelle spor. En måde kunne være at gøre case-skrivning til en akademisk ydelse, som var målbar på samme måde som videnskabelige artikler. Det kunne gøres ved fx at give plads til undervisningscases som kategori i indberetningssystemer som PURE (evt. suppleret med et peer review-system tilknyttet den førnævnte database). Et andet strukturelt tiltag kunne bestå i at afsætte midler til undervisningsudvikling, der overskrider det, der normalt falder inden for 'forberedelsestaksten'. En yderligere mulighed er en centralt koordineret satsning på udvikling af denne type undervisningsform, eventuelt med bidrag fra eksterne interessenter. Udbredelsen af casebaseret undervisning $\mathrm{i}$ andre sektorer af universitetsuddannelserne har krævet, at institutionen understøtter processen og allokerer midler til implementeringen (jf. Merseth, 1991). Det vil også være nødvendigt på humaniora. 
Forskning, erfaringsdeling og tilgængelige eksempler vil naturligvis ikke udrydde alle praktiske problemer. Det ovenstående er derfor ikke et argument for en revolution, der helt omtænker klassiske, humanistiske fag; der er også svagheder ved metoden: Den er tidskrævende at forberede og tidskrævende at afvikle, og det er også tænkeligt, at tilegnelse af visse former for viden ( $\mathrm{fx}$ om grammatiske strukturer, historisk overblik eller logisk teori) bedre opnås gennem andre undervisningsformer. Pointen er dog her, at case-baseret undervisning giver mulighed for at supplere og kvalificere den traditionelle undervisning, idet den er et værktøj, som forener nogle dyder, som er svære at virkeliggøre med andre metoder. Endvidere kan man forsøge sig i det små, inden man lægger hele sit forløb an på cases.

\section{Praktiske erfaringer støtter det teoretiske argument}

Den bedste metode til at vise, at noget kan lade sig gøre, er at gøre det. Derfor vil vi i det følgende flette nogle af vore egne erfaringer ind. Forfatterne til denne artikel har forsøgsvis arbejdet med case-baseret undervisning i fagene Etik, Videnskabsteori, Kristendomshistorie og Religionssociologi. Målet var oprindeligt at teste, hvorvidt metoden overhovedet var brugbar i humanistiske fag med vægt på vidensindlæring frem for beslutningstagen. I de konkrete tilfælde udarbejdede vi bl.a. cases til undervisning i protestantiske vækkelser i 19. århundredes kristendom (Indre Mission, grundtvigianisme og Tidehverv), i religion og lovgivning (religionsfrihed i Rusland) og i religionsvidenskabens videnskabsteori (religionsdefinitioner samt insider/outsider-tilgange til religion). Erfaringerne med udarbejdelsen af casene er først og fremmest disse: Case-undervisning er ressourcekrævende og mangler praktisk og institutionel støtte. Men det kan sagtens lade sig gøre at bruge case-baseret undervisning i vore klassiske, humanistiske fag, og casemetoden er givtig både for motivation, læring og faglighed. Desuden tilbyder den faktisk en genvej til implementering af Bologna-processen.

Brugen af cases i praksis

Et vist mål af kreativitet er en klar fordel i arbejdet med at skrive cases. Udarbejdelse af de ovennævnte cases krævede i første omgang inddragelse af fiktive karakterer, således at væsentlige problemstillinger kunne komprimeres til et format, som i omfang svarede til én undervisningsgang. Denne metode kan kritiseres i forhold til indlæring af kildekritik og -bevidsthed, men den har den fordel, at de studerende, i stedet for at læse adskillige artikler, som tilsammen kunne belyse undervisningens hovedemne, kunne få problematikkerne samlet i oversigtsform. Undervisningen kunne således tage udgangspunkt i mange flere problemstillinger end de ca. 50 siders oversigts- og kildelitteratur, som normalt indgår i en undervisningsgang på grundfagsniveau, og sværhedsgraden og kompleksiteten i problemstillingerne kunne derfor hæves. Samtidig gav case-metoden større mulighed for at tilpasse en given empiri til de problemstillinger og teorier, som vi ønskede at behandle. Fx bliver de religiøse væk- 
kelser i 1800-tallets Danmark i litteraturen typisk behandlet historisk. I det pågældende tilfælde var det ønsket at få religionssociologiske vinkler på bevægelserne i forhold til konversionsteori (dvs. hvorfor og hvordan mennesker ændrer deres religiøse tilhørsforhold). Ved at bruge cases er man som underviser ikke lige så afhængig af den tilgængelige litteratur (hvor, hånden på hjertet, måske kun en lille del af en artikel eller et bogkapitel er egentlig relevant) men kan tilpasse casen undervisningens formål. Metoden udelukker ikke, at de studerende trænes i at sætte sig ind i store stofmængder og udlede de centrale problemstillinger. Pointen er, at casemetoden giver mulighed for at komprimere denne proces, så det samlede læringsudbytte bliver højere.

\section{Gevinst for motivation, læring og faglighed}

Case-metoden er, som ovenfor nævnt stærkt studenterinvolverende. I og med at undervisningen bygges op omkring en diskussion af casen, deltager langt flere studerende, end hvad vi typisk ser til traditionel, forelæsningsbaseret undervisning. Det er velkendt, at læringsudbyttet er højere ved aktiv deltagelse (se fx Bligh, 1972 og McKeachie et al., 1990), og vores - kursoriske - erfaringer ved de efterfølgende eksaminer er da også, at de temaer, som blev behandlet i den case-baserede undervisning, sad fast og, når muligheden var tilstede, blev foretrukket som den selvvalgte ramme for den studerendes afsluttende prøve.

Der er imidlertid også en gevinst at hente i et større perspektiv. Implementeringen af Bologna-processen på de danske universiteter har indflydelse på udarbejdelse af kompetencemål i fagenes studieordninger. Hvor der traditionelt har været lagt vægt på indlæring af viden, er der i nyere studieordninger (siden 2006) krav om, at også færdigheder og kompetencer trænes (Karakterbekendtgørelsen, §19,1). Forskningen i case-baseret undervisning viser, at hvor traditionel undervisning egner sig udmærket (og i nogle undersøgelser bedre) til vidensindlæring er case-baseret undervisning suveræn, når det drejer sig om at træne de studerende i at løse komplekse problemstillinger, at se meningen med lærestoffet og at anvende deres viden (Strobel \& Barneveld, 2009). Med andre ord er case-baseret undervisning velegnet til at øve færdigheder og kompetencer.

\section{Sammenfattende}

Vi har argumenteret for at det både er muligt og pædagogisk fornuftigt af lektor Petersen og mange af hendes humanistiske kolleger at forsøge sig med undervisningscases i humaniora. Men vi har også peget på, at hvis metoden skal kunne få et gennembrud i denne del af universitetsundervisningen, kræver det mere forskning, mere uddannelsesudvikling og vidensdeling såvel som strukturelle incitamenter.

En fordel ved den case-baserede undervisning er dog, at metoden også kan fungere som supplement til den traditionelle undervisning. En storstilet implementering af 
case-baseret undervisning i humanistiske fag er næppe realistisk (og måske heller ikke ønskværdig), men metoden er særdeles anvendelig som supplement til traditionel undervisning og også velegnet til at fremme de mål som Bologna-processen fordrer implementeret.

Caroline Schaffalitzky de Muckadell er adjunkt i Religionsrelateret Filosofi ved Institut for Kulturvidenskaber ved Syddansk Universitet. Hun er ph.d. i Filosofi med en afhandling om religionsbegreber og hendes faglige profil omfatter derudover bl.a. videnskabsteori og filosofi med børn. Caroline er tidligere studieleder for filosofiuddannelserne ved Syddansk Universitet og har gennem årene varet involveret $i$ mange udviklingsopgaver i forbindelse med studieorganisering og undervisning.

Annika Hvithamar er lektor i Religionshistorie med særligt henblik på kristendom ved Institut for Historie, Syddansk Universitet. Hendes forskningsområde er ortodoks kristendom. Hun har været studieleder for Religion og har $i$ den forbindelse været ansvarlig for akkrediteringen af Religion og udarbejdelse af de seneste studieordninger til BA- og KA-uddannelsen.

Forfatterne har tidligere arbejdet sammen $i$ udvalg for proveformer og er i færd med at udvikle et efteruddannelseskursus for case-undervisning for humanister.

\section{Henvisninger}

Databaser

Case-method Website, University of Santa Barbara:

http://www.soc.ucsb.edu/projects/casemethod/caselist.html (tilgået 24.01.13).

Enduring Legacies: Native Case Studies: http://nativecases.evergreen.edu/ (tilgået 24.01.13).

Electronic Hallway: http://hallway.evans.washington.edu/ (tilgået 24.01.13).

National Center for Case Study Teaching in Science:

http://sciencecases.lib.buffalo.edu/cs/ (tilgået 24.01.13).

Online Ethics Center: http://www.onlineethics.org/ (tilgået 24.01.13).

\section{Litteratur}

Bekendtgørelse om karakterskala og anden bedømmelse ved universitetsuddannelser, lov af 8. juni 2006.

Biggs, J. \& Tang, C. (2009). Teaching for Quality at University (3. udg.). New York: Open University Press.

Bligh, D. (1972). What's the Use of Lectures. Harmondsworth: Penguin.

Constantino, M. \& Hurtado, D. (2007). Whose History Should We Teach?, http://nativecases.evergreen.edu/collection/cases/whose-history-should-weteach.html (tilgået 24.01.13)

Foran, J. (2001). The Case Method and the Interactive Classroom. I: Thought and Action 19(1), s. 41-50.

Jonassen, D. H. \& Hernanez-Serrano, J. (2002). Case-Based Reasoning and Instruc- 
tional Design: Using Stories to Support Problem Solving. I: Educational

Tehnology Research \& Development, 50(2), s. 65-77.

Hmelo-Silver C. E. (2004). Problem-Based Learning: What and How Do Students

Learn? I: Educational Psychology Review, 16(3), s. 235-266.

Levin, B. A., Harrington, H. L. \& Lundeberg, M. (1999): Who learns what from cases and how? The research base for teaching and learning with cases. Mahwah, N J. Erlbaum.

Lundeberg, M. A. \& Yadav, A. (2006). Assessment of case study teaching: Where do we go from here? Part I. I: Journal of College Science Teaching, 35(5), s. 10-13.

McKeachie, W. B., Pintrich, P.R., Lin, Y.-G. \& Smith, D.A.F. (1990). Teaching and Learning in the College Classroom: A Review of the Literature (2. udg.). Ann Arbor: University of Michigan, National Center for Research to Improve Postsecondary Teaching and Learning.

Merseth, K. (1991). The Early History of Case-Based Instruction: Insights for Teacher Education Today. I: Journal of Teacher Education, 42, s. 243-249.

Nilson, L. B. (2010). Teaching at its best. Research-based ressource for college instructors (3. ed.). San Fransisco: Jossey-Bass.

Savery, J. R. (1996). Overview of Problem-based Learning: Definitions and Distinctions. I: Interdisciplinary Journal of Problem-based Learning, 1(1), s. 9-20.

Strobel, J. \& van Barneveld, A. (2009). When is PBL More Effective? A Meta-synthesis of Meta-analyses Comparing PBL to Conventional Classrooms. I: Interdisciplinary Journal of Problem-based Learning, 3(1), s. 44-58.

Wheeler, A. \& Smith, B. L. (2009). Tse-Whit-Zen: An Ancient Klallam Village Reclaimed... Territory Taken but not Forgotten.

http://nativecases.evergreen.edu/collection/cases/tse-whit-zen.html (tilgået 24.01.13).

Anbefalet litteratur til caseundervisning i praksis

Herskin, B. (2009). Caseundervisning. I: Herskin, B., Undervisningsteknik for universitetslærere - formidling og aktivering. Frederiksberg: Samfundslitteratur, s. 201237.

Erskine, J. A., Leenders, M. R. \& Mauffette-Leenders, L.A. (2003). Teaching with cases (3. ed.). London, Ontario: Richard Ivey School of Business.

Mauffette-Leenders, L. A., Erskine, J. A. \& Leenders, M. R. (2001). Learning with cases (2. ed.). London, Ontario: Richard Ivey School of Business. 